\title{
Embryonic malformations in an offspring of the shortnose guitarfish
}

\author{
Natascha Wosnick', Verônica Takatsuka ${ }^{2}$, Ana Eliza Mello ${ }^{3}$,June Dias ${ }^{4}$, Nicolas Lubitz ${ }^{5}$, Venâncio \\ Guedes de Azevedo ${ }^{2 *}$
}

\author{
${ }^{1}$ Associação MarBrasil \\ (R. Rosa Gonçalves dos Santos, 300 - Pontal do Paraná - PR - 83255-000 - Brazil \\ ${ }^{2}$ Núcleo Regional de Pesquisa do Litoral Norte, Instituto de Pesca \\ (Estrada Professor Joaquim Lauro Monte Claro, 2275 - Praia do Itaguá - Ubatuba - SP - 11680-000 - Brazil) \\ ${ }^{3}$ PetCenter, Clínica Veterinária \\ (Rodovia Oswaldo Cruz - Jardim Carolina, Ubatuba - SP - 11680-000 - Brazil) \\ ${ }^{4}$ Instituto Oceanográfico da Universidade de São Paulo \\ (Praça do Oceanográfico, 191 - Butantã - SP - 05508-120 - Brazil) \\ ${ }^{5}$ Earth \& Environmental Sciences, James Cook University, Townsville, QLD \\ (1 James Cook Dr, Townsville City QLD 4814, Austrália) \\ *Corresponding author: vazevedo@pesca.sp.gov.br
}

\section{ABSTRACT}

Embryonic malformations can be a result of exposure toxic substances (pollution), lack of nutrients, physical restraint, genetic disorders, or infections and diseases. Such malformations can be classified according to severity and offspring survival outside the uterus. Moreover, abnormalities are normally restricted to a small portion of the litter, mostly, to only one embryo. Here, we report a case of congenital malformation dominance in an offspring of the shortnose guitarfish and compare it with other abnormalities commonly reported in batoids in addition to discussing the possible causes involved in the observed deformities.

Descriptors: congenital anomalies; maternal health; guitarfish.

A teratogen is any environmental, infectious or nutritional agent capable of producing developmental disturbances or congenital malformations in an embryo after maternal exposure to it (Mahan and Escott-Stump, 2003). A fundamental difference between a malformation caused by a mutation and one resulting from a teratogenic agent is that, in the latter case, there is no change in the genetic load. Consequently, there is no risk of transmission to offspring when the affected individual reproduces. Despite knowledge that a teratogenic agent can lead to congenic anomalies in several organisms, the critical stage of development in which exposure must occur so that the effects are manifested remains unknown. However, it is known that the main mechanisms by which a teratogen acts are

Submitted on: 30/May/2019

Approved on: 27/August/2019

http://dx.doi.org/10.1590/S1679-87592019027306710

Associate Editor: Daniel E. L. Lemos inhibition of cell proliferation and protein synthesis, generalized cell death and changes in differentiation patterns and morphogenic interactions (Shepard et al., 1975).

Reports on teratogenesis are relatively common in elasmobranchs (Templeman, 1965; Bornatowski and Abilhoa, 2009; Delpiani et al., 2011; Suresh and Raff, 2012; dos Santos and Gadig, 2014; Moore, 2015). Among the abnormalities already identified for this group, deformities in the pectoral fins in batoids (i.e., fins not fused to the head) (Templeman, 1965; Rosa et al., 1996; Bornatowski and Abilhoa, 2009; Suresh and Raff, 2012) and conjoined shark embryos are most commonly observed (Delpiani et al., 2011; dos Santos and Gadig, 2014; Lamarca et al., 2017; Sans-Coma et al., 2017). While some malformations are mild and not very extensive, some are severe enough to cause mortality. If not at the embryonic level, certainly after birth due to subsequent ecological restrictions (e.g., feeding efficiency, predator detection, 
or internal deformities that may cause systemic failure) (Muñoz-Osorio et al., 2013; dos Santos and Gadig, 2014).

To date, congenital anomalies have been described only for viviparous species, given the greater maternalfetal interaction in this reproductive mode. However, occurrence is not restricted to matrotrophy, since reports in lecithotrophic species are also common (Ribeiro-Prado et al., 2008; Bornatowski and Abilhoa, 2009; Carmo and Fávaro, 2015). Zapteryx brevirostris (Müller and Henle, 1841) is a small-sized guitarfish, endemic to the Southwest Atlantic, with a lecithotrophic viviparous mode and up to 6 embryos per litter (Figueiredo, 1977; Batista, 1991). In Southern Brazil, the embryonic development period occurs during spring, with birth occurring in warmer months (December to March) (Batista, 1991; Abilhoa et al., 2007). Reports on Z. brevirostris malformations are recent, with only two occurrences described in the literature, one related to an embryo malformation (one in a litter of five embryos) (Carmo and Fávaro, 2015) and another being a case of anophthalmia in an adult female (Ribeiro-Prado et al., 2008). Here, we report for the first time an occurrence of congenital malformation in multiple embryos of the same offspring, compare them with abnormalities commonly found in other elasmobranchs and discuss possible causes for the alterations observed.

One adult female was captured as bycatch of shrimp trawling on the northern coast of São Paulo (SISBIO 49980-3 and Ethics Committee on Animal Use of the Fisheries Institute - CEEAIP 12 / 2016). The female was caught in the last haul of the trawl and transferred to a 200L styrofoam box, with constant aeration and water circulation. Afterwards, it was transported to the laboratory facilities and acclimatized in a 2500L glass fiber tank. Food was offered once a day in a satiety feeding regime, consisting of beheaded Atlantic seabob shrimp, Xiphopenaeus kroyeri (Heller, 1862). After acclimation, the female, along with other individuals of the same species, was used in experiments aiming to evaluate the influence of different sediments on behavior and physiological performance (unpublished data). After the experimental period (18 days), the specimen was euthanized through exposure to high dosage of anesthetic (eugenol diluted in alcohol 15$168 \mathrm{mg} / \mathrm{L}$ ) for the assessment of systemic condition.

During necropsy, pregnancy was detected. Five embryos were present and four of them exhibited anatomical malformations. Internal observations were made through $\mathrm{X}$-rays, taken by CDK trigger and an Agfa CR 10 digitizer with the following configurations: KV 40 and mAs of 6.4.
The embryos were held in dorsal position for diagnosis. All embryos were carefully evaluated, and the description of the deformities is given below.

Specimen one: mild malformations; absence of the final portion of the tail; no signs of fracture; X-ray diagnosis revealed no formation of the final portion of the tail (total length $-6.9 \mathrm{~cm}$, disc width $-3.9 \mathrm{~cm}$, weight $-4 \mathrm{~g}$ ) (Figure 1a). Specimen two: mild malformations; fins not fully fused in the lateral portions of the tail base; X-ray diagnosis revealed a midline malformation in the final portion of the tail (total length $-7.9 \mathrm{~cm}$, disc width $-3.5 \mathrm{~cm}$, weight 2.1g) (Figure 1b). Specimen three: severe malformations; both pectoral fins not fully fused in the cephalic region; $\mathrm{X}$-ray analysis diagnosis revealed midline deformation at the last portion of the tail, a mild midline deviation in the pelvic girdle region and fused gills (total length $-7.8 \mathrm{~cm}$, disc width $-3.2 \mathrm{~cm}$, weight - 2.6g) (Figure 1c). Specimen four: severe malformations; pectoral fins not fully fused in the cephalic region, with a more pronounced deformation in the right pectoral fin; malformation of both pelvic fins; severe midline deviation in the pelvic girdle region that extended to the entire caudal region (total length $-8 \mathrm{~cm}$, disc width $-3.8 \mathrm{~cm}$, weight - 3g) (Figure 1d). Specimen five: fully formed, with no signs of external or internal abnormalities (total length $-9.2 \mathrm{~cm}$, disc width $-4 \mathrm{~cm}$, weight - 4.4g) (Figure 1e). Given the birth size of the species ( $14 \mathrm{~cm}$ in TL - Batista, 1991), it was estimated that female was in the third trimester of pregnancy (12 months in the species - Batista, 1991)

The abnormalities observed in the present study were related to morphological alterations of the pectoral fins and spinal malformation. In a recent survey, some occurrence patterns were observed, with females being more affected than males, and malformations in the cephalic region (chondrocranium deformation) and pelvic fins being the most commonly observed in batoids and sharks (Nunes et al., in prep). Still, studies show that spinal deformations such as lordosis, scoliosis and kyphosis are also common but less deleterious (Berzins et al., 2002; Preziosi et al., 2006; Pérez et al., 2018), with lower mortality rates. Nonetheless this may be associated with negative consequences, as swimming capacity may be hampered (Muñoz-Osorio, et al., 2013; dos Santos \& Gadig, 2014).

The offspring of the present study indeed presented the most commonly observed deformities in elasmobranchs, however at a frequency never reported in the literature, since $80 \%$ of embryos had morphological alterations. Such a phenomenon, although occurring in elasmobranchs 


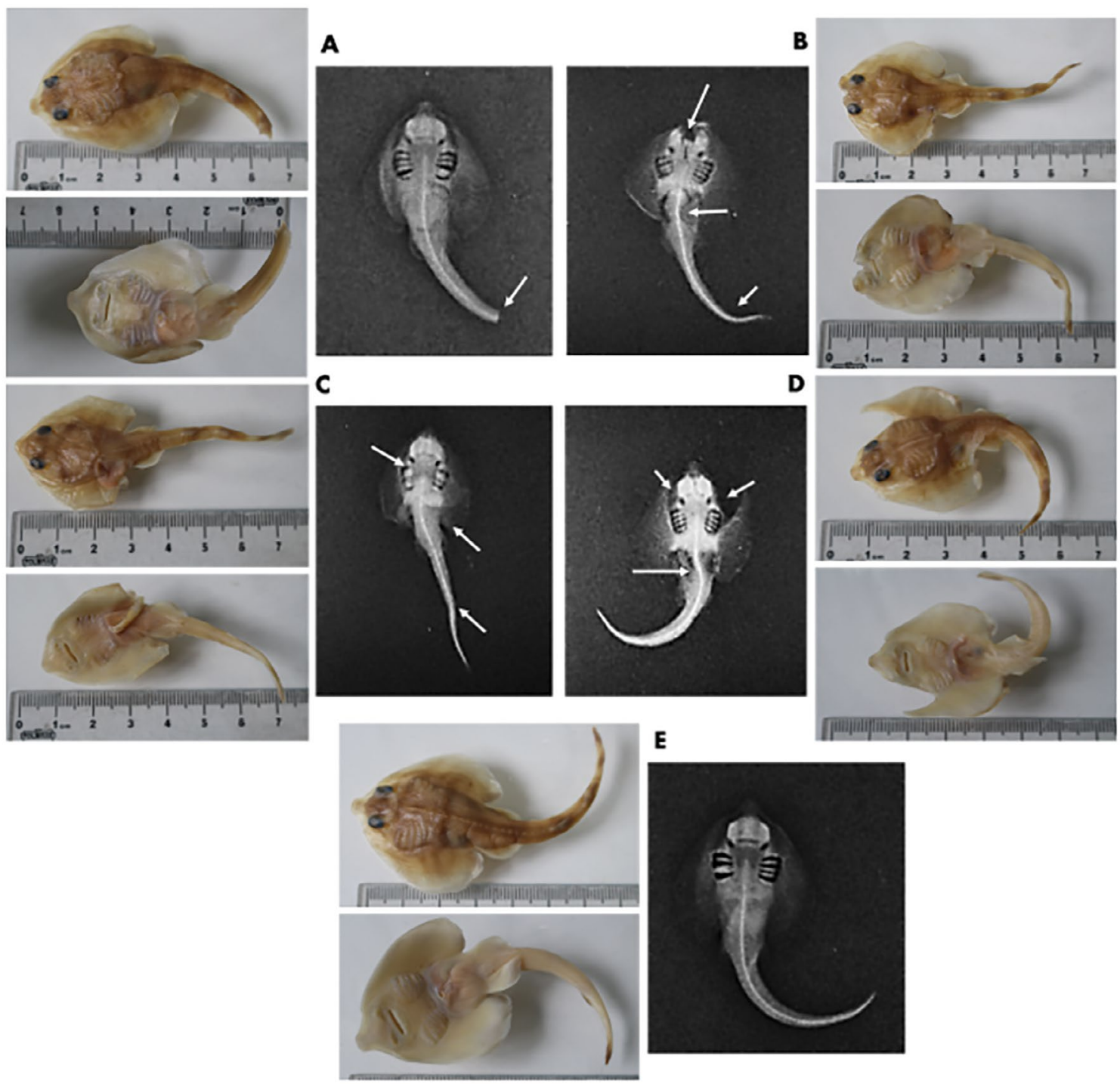

Figure 1. Offspring analyzed in the present study. (a) specimen one presenting mild malformations; (b) specimen two presenting mild malformations; (c) specimen three presenting moderate malformations; (d) specimen four presenting severe malformations and (e) specimen five in perfect conditions.

that have more than one developing embryo at the same time, appears to have low occurrence in the same offspring, with usually only one or two embryos exhibiting significant morphological alterations (Bornatowski and Abilhoa, 2009; dos Santos and Gadig, 2014; Carmo and Fávaro, 2015; Lamarca et al., 2017). This fact is of significance, since all embryos are exposed to the same uterine conditions and maternal-fetal interactions, thus future studies aiming to understand why malformations are not prevalent within an offspring should be carried out.
Since in the present study most of the offspring presented significant morphological alterations, it is possible that the phenomenon was related to exposure to a teratogen in the initial stages of embryonic development. In fact, there is strong evidence that the most serious congenital malformations are related to exposure during the critical period of differentiation and organogenesis, since at this stage the embryo is more vulnerable to changes at the structural level (Nelson, 1957). Also, among the teratogenic agents mentioned above, it is possible that the 
malformations reported are related to female starvation and/or severe nutritional deficiency in the wild rather than exposure to environmental contaminants, due to the predominance observed. Such inference is based on a study performed with pregnant round stingrays (Urobatis helleri) (Cooper, 1863) exposed to contaminants, with significant alterations on female's metabolism, but no embryonic malformation (Lyons, 2018).

In summary, here we present the first report of embryonic malformation predominance in an elasmobranch. Although the causes are reason for speculation, such occurrence is extremely significant as it increases the knowledge about congenital malformations in this group, as well as offering new perspectives in terms of the frequency of occurrence.

\section{REFERENCES}

ABILHOA, V., BORNATOWSKI, H. \& FREITAS, M. O. 2007. Some information on reproduction and embryonic development of the lesser guitarfish Zapteryx brevirostris in Southern Brazil. Acta Adriatica, 48, 185-190.

BATISTA, V. S. 1991. Aspectos quantitativos da fecundidade e do desenvolvimento embrionário da raia Zapteryx brevirostris Müller \& Hendle, 1841 (Pisces, Rhinobatidae) da enseada de Itaipu, Niterói, Rio de Janeiro. Revista Brasileira de Biologia, $51,495-501$.

BERZINS, I. K., WALSH, M. \& RICHARDS, M. 2002. Spinal deformities in captive sand tiger sharks (Carcharias taurus). In: Proc. 27th Ann. Eastern Fish Health Workshop, Mount Pleasant, SC, pp. 18-20.

BORNATOWSKI, H. \& ABILHOA, V. 2009. Record of an anomalous embryo of Rhinobatos percellens (Elasmobranchii: Rhinobatidae) in the southern coast of Brazil. Marine Biodiversity Records, 2, e36.

DELPIANI, S. M., DELI ANTONI, M. Y., BARBINI, S. A. \& FIGUEROA, D. E. 2011. First record of a dicephalic specimen of tope Galeorhinus galeus (Elasmobranchii: Triakidae). Journal of Fish Biology, 78, 941-944.

CARMO, W. P. D. \& FÁVARO, L. F. 2015. Teratogenic processes in an embryo without gills and low yolk absorption of Zapteryx brevirostris (Elasmobranchii: Rhinobatidae). Brazilian Journal of Oceanography, 63, 497-500.

DOS SANTOS, C. M. H. \& GADIG, O. B. F. 2014. Abnormal embryos of sharpnose sharks, Rhizoprionodon porosus and Rhizoprionodon lalandii (Elasmobranchii: Carcharhinidae), from Brazilian coast, western South Atlantic. Marine Biodiversity Records, 7, e55.

FIGUEIREDO, J. L. 1977. Manual de peixes marinhos do sudeste do Brasil. I. Introdução. Cações, Raias e Quimeras, São Paulo, Museu de Zoologia da Universidade de São Paulo.
JEZIERSKA, B., ŁUGOWSKA, K. \& WITESKA, M. 2009. The effects of heavy metals on embryonic development of fish (a review). Fish Physiology and Biochemistry, 35, 625-640.

LAMARCA, F., RIBEIRO, N., GALHEIGO, F., \& VIANNA, M. 2017. The first record of diprosopus tetrophthalmus in the South Atlantic Ocean: the case of Prionace glauca (Elasmobranchii: Carcharhiniformes: Carcharhinidae) in Brazil. Acta Ichthyologica et Piscatoria, 47, 385-389.

LYONS, K. 2018. Physiological consequences of environmental contamination in an elasmobranch with matrotrophic histotrophy, the Round Stingray (Urobatis halleri), Alberta, Canada, University of Calgary.

MAHAN, L. K. \& ESCOTT-STUMP, S. 2003. Krause: Alimentos, Nutrição e Dietoterapia, São Paulo: Rocca.

MUÑOZ-OSORIO, L. A., MEJÍA-FALLA, P. A., NAVIA, A. F. 2013. First record of a bicephalic embryo of smalltail shark Carcharhinus porosus. Journal of Fish Biology, 82, 17531757.

NELSON, M. M. 1957. Production of congenital anomalies in mammals by maternal dietary deficiencies. Pediatrics, 19, 764-776.

PÉREZ, A. E., BORGES, S. M., OLIVARES, F. R. \& RAREDON, S. J. 2018. First Case of Morphological Abnormality in Common Angel Sharks Squatina squatina. (Chondrichthyes: Squatinidae), from the Canary Islands. Turkish Journal of Fisheries and Aquatic Sciences, 19, 267-270.

PREZIOSI, R., GRIDELLI, S., BORGHETTI, P., DIANA, A., PARMEGGIANI, A., FIORAVANTI, M. L., MARCER, F., BIANCHI, I., WALSH, M. \& BERZINS, I. 2006. Spinal deformity in a sand tiger shark, Carcharias taurus Rafinesque: a clinical-pathological study. Journal of Fish Diseases, 29, 49-60.

RIBEIRO-PRADO, C. C., ODDONE, M. C., BUENO GONZALEZ, M. M., FERREIRA DE AMORIM, A. \& CAPAPÉ, C. 2008. Morphological abnormalities in skates and rays (Chondrichthyes) from off southeastern Brazil. Arquivos de Ciências do Mar, 41, 21-28.

SANS-COMA, V., RODRÍGUEZ, C., LÓPEZ-UNZU, M. A., LORENZALE, M., FERNÁNDEZ, B., VIDA, L. \& DURÁN, A. C. 2017. Dicephalous v. diprosopus sharks: record of a two-headed embryo of Galeus atlanticus and review of the literature. Journal of Fish Biology, 90, 283-293.

SHANG, E. H. \& WU, R. S. 2004. Aquatic hypoxia is a teratogen and affects fish embryonic development. Environmental Science \& Technology, 38, 4763-4767.

SHEPARD, T. H., MILLER, J. R. \& MAROIS, M. 1975. Methods for detection of environmental agents that produce congenital defects, Amsterdam: North-Holland Publishing Company.

SURESH, T. V. \& RAFFI, S. M. 2012. Pectoral fin anomalies in the long-tailed butterfly ray, Gymnura poecilura collected from Nagapattinam coastal waters, south-east coast of India. Marine Biodiversity Records, 5, e95.

TEMPLEMAN, W. 1965. Some abnormalities in skates (Raja) of the Newfoundland area. Journal of the Fisheries Research Board of Canada, 22, 237-238. 